\title{
PELATIHAN MODIFIKASI PRODUK DAN MARKETING DIGITAL DI ERA PANDEMI: UMKM PRODUKSI EMPING DESA PANCUR-TAKTAKAN KOTA SERANG
}

\author{
Puspita Maelani', Khafidz Rois² ${ }^{2}$, Fawza Fahira ${ }^{3}$. \\ ${ }^{123}$ Universitas Bina Bangsa. \\ Email:1puspita.maelani91@gmail.com, 2fawzafhrs@gmail.com, ${ }^{3 k h a f i d z . r o i s 68 @ g m a i l . c o m ~}$
}

\begin{abstract}
MSMEs are trading businesses carried out by individuals or groups that refer to productive economic businesses. The business carried out by individuals or groups in the village of Sepring, Pancur Village, Taktakan, is a processed business from melinjo, namely emping. Conventional marketing, namely by marketing directly to local markets or areas, products that are still original chips, and the Covid-19 pandemic are obstacles for MSMEs. This training method has stages, the first stage is a direct survey to see the production and marketing process of MSMEs, the second stage is planning and finally implementation. The result of this training activity is that it can increase the knowledge of MSME business actors about the legality and licensing of institutions or products, knowledge about modifying products according to market needs and implementing digital marketing through a marketplace or online shop in collaboration with village youths.
\end{abstract}

Keywords: Modification, Digital Marketing, MSMEs.

\begin{abstract}
Abstrak
UMKM merupakan usaha perdagangan yang dilakukan oleh perorangan maupun kelompok yang merujuk pada usaha ekonomi produktif. Usaha yang dilakukan oleh perorangan atau kelompok di kampung sepring desa pancur kota taktakan adalah usaha olahan dari melinjo, yaitu emping. Pemasaran yang masih konvensional, yaitu dengan memasarkan langsung ke pasar atau daerah lokal, produk yang masih original emping, dan kondisi pandemi Covid-19 menjadi hambatan tersendiri bagi UMKM. Metode pelatihan ini memiliki tahapan-tahapan, tahapan pertama survey langsung untuk melihat proses produksi dan marketing dari UMKM, tahapan kedua adalah perencanaan dan etrakhir pelaksanaan. Hasil kegiatan pelatihan ini adalah dapat meningkatkan pengetahuan pelaku usaha UMKM tentang legalitas dan perijinan lembaga atau produk, pengetahuan tentang memodifikasi produk sesuai kebutuhan pasar dan menerapkan marketing digital melalui marketplace atau onlineshop dengan kerjasama para pemuda kampung sepring.
\end{abstract}

Kata Kunci: Mofikikasi, Marketing Digital, UMKM.

\section{PENDAHULUAN}

Pelatihan merupakan serangkaian aktivitas individu dalam meningkatkan keahlian dan pengetahuan secara sistematis sehingga mampu memiliki kinerja yang profesional di bidangnya. Tujuan pelatihan untuk meningkatkan produktivitas kualitas, mendukung perencanaan SDM, meningkatkan moral anggota, memberikan kompensasi yang tidak 
langsung, meningkatkan keselamatan dan kesehatan kinerja, mencegah kadaluarsa kemampuan dan pengetahuan personal, meningkatkan perkembangan kemampuan dan keahlian personal (Widodo, 2015). Menurut Rivai dan Sagala (2011), pelatihan adalah proses secara sistematis mengubah tingkah laku pegawai untuk mencapai tujuan organisasi.

Adapun prinsip-prinsip pada pelatihan menurut Sofiyandi(2013) pertama dalam pelaksanaan pelatihan para peserta harus ikut aktif karena dengan partisipasi peserta akan lebih cepat menguasai dan mengetahui berbagai materi yang diberikan adalah participation. Kedua saling berhubungan sebagai contoh para peserta pelatihan terlebih dahulu diberikan penjelasan secara umum tentang pekerjaan sebelum mereka mempelajari hal-hal khusus dari pekerjaan tersebut adalah Relevance. Ketiga program pelatihan harus disesuaikan dengan kebutuhan-kebutuhan yang nantinya akan dihadapi dalam pekerjaan yang sebenarnya adalah Transference. Keempat senantiasa dilakukan secara berulang karena peserta akan lebih cepat untuk memenuhi dan mengingat apa yang telah diberikan adalah Repetition. Kelima setiap program pelatihan yang dilaksanakan selalu dibutuhkan umpan balik yaitu untuk mengukur sejauh mana keberhasilan dari program pelatihan tersebut adalah Feedback.

Pelatihan berkaitan dengan keahlian dan kemampuan pegawai untuk melaksanakan pekerjaan saat ini. dari beberapa pengertian dapat disimpulkan bahwa penelitian merupakan proses aktivitas idnividu maupun kelmpok yang terencana,dan mempunyai tujuan adanya perubahan keahlian atau kemampuan seoarang individu maupun kelompok.

Modifikasi merupakan Setiap perubahan yang dibuat pada suatu produk (ukuran, bentuk, warna, gaya, harga, dll). Modifikasi produk biasanya dilakukan sebagai usaha merevitalisasi produk tersebut untuk meningkatkan permintaan. Modifikasi produk ini bertujuan untuk meningkatkan volume penjualan dengan cara memodifikasi karakteristik produk melalui peningkatan mutu produk, peningkatan ciri-ciri atau fitur-fitur produk, dan peningkatan model produk.

Pemasaran merupakan mengidentifikasi dan memenuhi kebutuhan manusia dan sosial. Salah satu definisi yang baik dan singkat dari pemasaran adalah memenuhi kebutuhan dengan cara yang menguntungkan menurut Kotler and Keller (2012). Langkah-langkah dalam pemasaran produk yaitu kenali pelanggan dengan baik, melakukan promosi yang tepat, bangun tempat usaha yang strategis, membuat anggaran sistematis, menjalin hubungan yang baik denga pelanggan, membuat toko online sendiri, memiliki media sosial, aktifkan email marketing dan langkah terakhir adalah menjalankan bisnis sistem dropship (system 
dengan sistem penjualan di mana penjual atau dropshipper hanya perlu memasarkan dan menjual barang milik pihak lain tanpa perlu membelinya terlebih dahulu (menyetok barang).

Pemasaran digital adalah salah satu media pemasaran yang kini sedang banyak diminati oleh masyarakat dalam mendukung banyak kegiatan (Pradiani, 2017). Manfaat dari pemasaran digital yaitu kecepatan penyebaran produk, kemudahan evaluasi, dan jangkauan lebih luas, murah dna efektif, dan membangun nama brand. Selain itu pemasaran digital memiliki keuntungan dan kelemahan menurut (Markerter, 2017) antara lain keuntungan pemasaran digital yaitu dapat menghubungkan produsen dengan konsumen melalui internet, mendapatkan penghasilan penjualan lebih tinggi dikarenakan semakin sempit jarak dan waktu.

Emping merupakan salah satu produk yang dihasilkan oleh kampung sepring, pancur taktakan kota serang. Masyarakat ini memanfaatkan hasil bumi berupa tangkil dengan hasil olahannya adalah produk emping. Produk emping sendiri, dikonsumsi baik secara langsung maupun sebagai pelengkap makanan. Namun seiring berjalannya perkembangan selera masyarakat, dan kondisi pasar. Peminat emping makin sedikit, dikarenakan ada produk baru yang serupa, yang lebih menairk perhatian konsumen. Ditambah dengan kondisi pandemik covod-19, pemerintahpun berinisiatif untuk mengurangi segala aktivitas dan mobilisasi lainnya, untuk mengurangi penularan covid-19 yang terus melonjak, maka dari itu pemasaran yang dilakukan oleh pelaku usaha UMKM emping makin terbatas.

Permaslahan yang dihadapi oleh pelaku usaha UMKM adalah kesulitan pemasaran, mereka masih memasarkan produknya lewat warung-warung daerah local dan pasar tradisional, dan itu pun jika tidak laku akan dikembalikan oleh pihak warung atau pasarnya. Permasalahan selanjutnya mereka masih minimnya edukasi dari dinas terkait, yyakni disperindag kota serang, hal ini dikarenakan UMKM mereka sendiri belum terdaftar di dinas terkait. Sehingga saat ada pendampingan baik edukasi maupun bantuan mereka tidak mendapatkannya. Selanjutnya, mereka dihadapkan dengan minimnya penggunaan teknologi yang sekarang semua kegiatan atau aktivitas dilakukan lewat teknologi.

Berdasarkan latar belakang tersebut, perlu dilakukan pelatihan modifikasi produk dan marketing digital di era pandemu: UMKM produk emping. Pelatihan yang dilakukan diharapkan dapat membantu dalam pemasaran produk yang dihasilkan secara digital melalui aplikasi marketplace atau onlineshop sehingga empping dapat dikenal oleh masyarakat luas. 


\section{METODE}

Pelatihan modifikasi produk dan marketing digital di era pandemi diikuti oleh para pelaku usaha UMKM emping dan pemuda. Pelatihan dilaksanakan secara tatap muka di ruangan kelas SDN Sepring Desa Pancur dengan tetap mematuhi protokol kesehatan dan sekaligus membagikan hansanitizer dan masker kepada para peserta.

Pelatihan ini mendatangkan dua narasumber, narasumber pertama dari DISPERINDAG Kota Serang tentang peran UMKM di era pandemik, materi tentang pera UMKM ini mentikberatkan pada bagaimana kualitas dari produk itu sendiri, dengan legalitas seperti P-IRT dan ijin legalitas lainnya. Dan cara-cara UMKM untuk tetap bertahan dengan kondisi pandemi ini tentunya lewat pendampingan dari DISPERINDAG sendiri. Kemudian dilanjutkan materi tentang modifikasi dan marketing digital, oleh dosen Universitas Bina Bangsa dan TIM KKM Tematik Desa Pancur. Materi ini menjelaskan bagaimana inovasi produk emping yang tidak hanya digoreng dengan satu jenis rasa, modifikasi ini mensimulasikan produk emping dengan olahan coklat dan permen (remahan emping) dan cara mendesain produk agar menarik perhatian konsumen. Setelah itu penjelasan tentang langkah-langkah dalam memahami marketplace dan onlineshop, penggunaan marketplace dengan langkah-langkah membuka tokooline salah satunya di tokopedia, dijelaskan mulai dari cara membuka took sampai pengelolaan toko di tokopedia. Untuk onlineshop mengarahkan langkah-langkah salah satunya seperti domainesia, dimulai dari mengenal jenis-jenis website, dan pengelolaan website sendiri.

Permasalahan pada pelaku usaha UMKM yang kurang mengerti penggunaan marketplace ataupun onlineshop, pelatihan ini pun mengundang para pemuda kampung sepring. Para pemuda dilatih tentang kewirausahaan dengan menggunakan marketing digital, ini bentuk kerjasama antara pemuda dan pelaku usaha UMKM. Adapun tahapan pelatihan modifikasi produk dan marketing digital di era pandemi Desa Pancur adalah sebagai berikut:

1. Survey

Survey dilakukan untuk mengetahui proses produksi dan marketing dari para pelaku usaha. Hal ini dilakukan untuk mengetahui dan membuat analisis SWOT dari UMKM.

2. Perencanaan

Perencanaan dilakukan dalam memenuhi kebutuhan yang diperlukan untuk memudahkan penyampaian informasi. Langkah pertama yaitu menentukan modifikasi produk yang digunakan dan menentukan contoh marketplace ataupun onlineshop 
untuk memasarkan produk dan membuat akunnya, kemudian menentukan jadwal pelatihan dan merumuskan materi yang akan disampaikan saat pelatihan serta memenuhi kelengkapan yang diperlukan selama pelatihan.

3. Pelaksanaan

Pelatihan dilaksanakan selama satu hari di ruangan SDN Sepring Pancur pada tanggal 15 Agustus 2021. Mengedukasi produsen dan pemuda untuk memahami cara modifikasi produk, seperi olahan emping coklat berwarna-warni dan permen (remahan emping), dan langkah-langkah dalam mengelola marketplace (tokopedia) dan onlineshop (domainesia), untuk memasarkan produk menjadi tujuan penting dalam pelatihan ini.

\section{HASIL DAN PEMBAHASAN}

Pelaksanaan pelatihan modifikasi produk dan marketing digital di era pandemi desa Pancur bagi produsen emping dan pemuda telah sukses dilaksanakan. Pelatihan dilaksanakan untuk memberikan pengetahuan dan selama satu hari pada tanggal 15 Agustus 2021 dengan tujuan untuk memberikan pemahaman kepada pelaku usaha UMKM dan pemuda mengenai cara memodifikasi produk dan marketing digital. Dengan adanya pelatihan ini pelaku usaha UMKM emping dan pemuda dapat menggunakan marketplace salahsatunya tokopedia ataupun onlineshop seperti domainesia, penggunaan marketplace dan onlineshop ini bertujuan untuk melakukan promosi dengan mudah dan produk yang telah dibuat dapat dikenal oleh masyarakat luas sehingga sangat memudahkan dalam proses penjualannya. Adapun indikator tercapainya tujuan dan tolak ukur keberhasilan pelatihan adalah sebagai berikut:

Table 1: Indikator Tercapainya Tujuan dan Tolak Ukur Keberhasilan Pelatihan

\begin{tabular}{|c|c|c|}
\hline Tujuan & Indikator Ketercapaian & Tolak Ukur \\
\hline 1. Memberikan & - Pemahaman & - Mampu menerapkan \\
\hline Pelatihan kualitas & terhadap langkah- & langkah-langkah \\
\hline produk (kebersihan, & langkah membuat & membuat produksi \\
\hline kehalalan, cita rasa) & produksi yang baik & yang baik dan benar. \\
\hline 2. Memberikan & dan benar & - Mampu mengurus \\
\hline pelatihan cara & - Pemahaman tentang & persyaratan- \\
\hline legalitas UMKM dan & langkah-langkah & persyaratan yang \\
\hline P-IRT dan ijin lainnya & dalam mengurus & berhubungan dengan \\
\hline
\end{tabular}




\begin{tabular}{|c|c|c|}
\hline & $\begin{array}{l}\text { perijinan baik ijin } \\
\text { produksi maupun } \\
\text { UMKM }\end{array}$ & $\begin{array}{l}\text { perijinan produksi } \\
\text { maupun UMKM }\end{array}$ \\
\hline $\begin{array}{l}\text { 3. Memberikan } \\
\text { pelatihan modifikasi } \\
\text { produk }\end{array}$ & 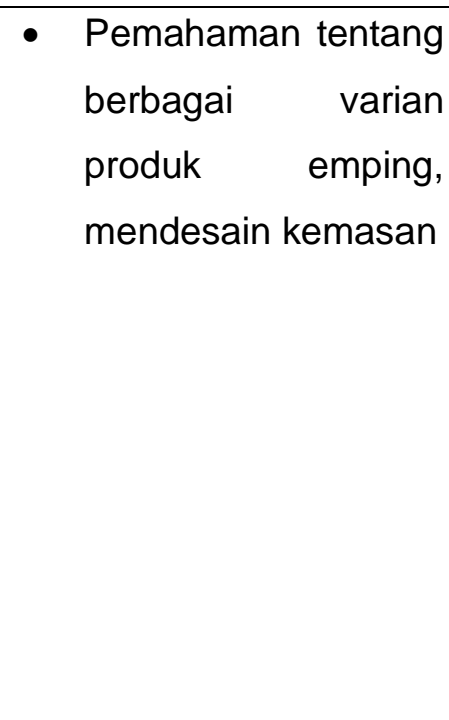 & $\begin{array}{l}\text { - Mampu menerapkan } \\
\text { langkah-langkah } \\
\text { dalam mengelola } \\
\text { produk emping dalam } \\
\text { berbagai varian atau } \\
\text { rasa } \\
\text { - Mampu } \\
\text { merencanakan dan } \\
\text { menggambarkan } \\
\text { desain kemasan yang } \\
\text { menarik }\end{array}$ \\
\hline $\begin{array}{l}\text { 4. Memberikan } \\
\text { pelatihan marketing } \\
\text { digital }\end{array}$ & $\begin{array}{l}\text { - Pemahaman tentang } \\
\text { pentingnya } \\
\text { penggunaan } \\
\text { teknologi dimasa } \\
\text { pandemi } \\
\text { - Pemahaman tentang } \\
\text { strategi marketing } \\
\text { - Pemahaman tentang } \\
\text { perbedaan } \\
\text { marketplace dan } \\
\text { onlineshop }\end{array}$ & $\begin{array}{l}\text { - } \text { Mampu menerapkan } \\
\text { langkah-langkah } \\
\text { menggunakan } \\
\text { marketplace seperti } \\
\text { tokopedia dan } \\
\text { onlineshop seperti } \\
\text { domainesia }\end{array}$ \\
\hline
\end{tabular}

Kegiatan pelatihan dilakukan dalam dua sesi yakni sesi pertama berkaitan dengan materi tentang peran UMKM di era pandemi, sesi ini yang dijelaskan dari tim DISPERINDAG Kota Serang, yang menjelaskan tentang bagaimana pentingnya UMKM untuk bertahan di kondisi pandemi, menjelaskan tentang langkah-langkah membuat produk makanan yang baik dan benar. Dan menjelaskan tentang langkah-langkah perijinan atau legalitas lembaga UMKM dan perijinan produk untuk siap edar, sehingga dengan adanya data UMKM yang tercatat di 
DISPERINDAG, maka akan ada penampingan jangka panjang untuk UMKM yang sudah terbagi disetiap kecamatan.

Sesi kedua berkaitan tentang modifikasi produk dan marketing digital. Materi ini menjelaskan tentang bagaimana cara memodifikasi produk dengan memperagakan atau mensimulasikan produk olahan emping dengan cita rasa yang berbeda, seperti emping coklat dan permpen emping. Materi ini juga menjelaskan tentang penggunaan marketplace dan onlieshop sebgaai cara untuk memasarkan produksi agar dikenal lebih oleh masyarakat luas. Penggunaan onlineshopdi contohkan seperti pembuatan website di domainesia, mulai dari pendafatraan sampai dengan website onlineshopnya jadi dengan nama took pelaku usaha UMKM. Utnuk marketplace dicontohkan menggunakan tokopedia, sama speerti onlineshop disini juga peserta pelatihan diajarkan bagaiman membuka toko di tokopedia.

Kembali dengan permasalahan yang dihadapi oleh pelaku usaha UMKM sendiri, yang mereka tidak semua dapat memahami penggunaan teknologi untuk marketing maka dari itu, pelatihan ini juga mengarahkan pada pemuda kampung sempring sebagai bentuk kerjasama dengan pelaku usaha, para pemuda yang siap berusaha untuk beriwirausaha menggunakan teknologi dengan produk dari pelaku usaha UMKM emping sendiri. Dibawah ini merupakan dokumentasi dari pelaksanaan pelatihan modifikasi produk dan marketing digital di era pandemi desa Pancur Taktakan Kota Serang. 


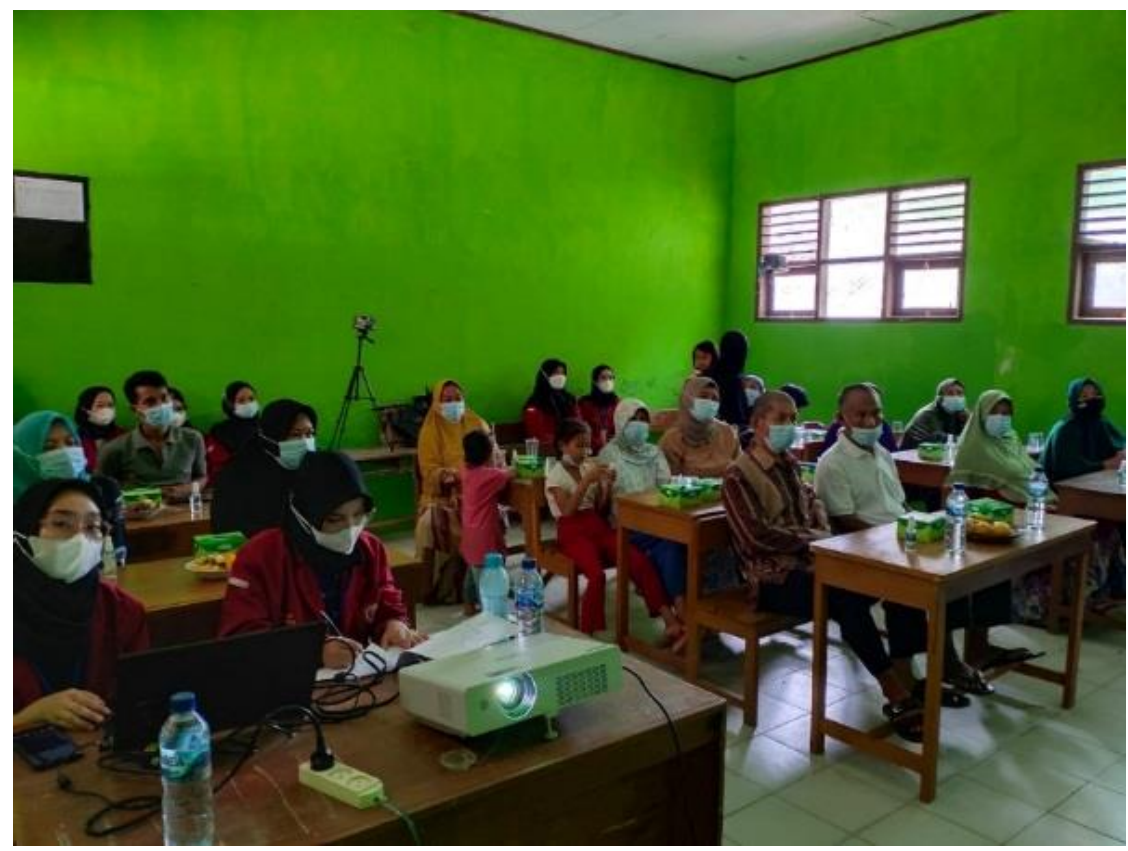

Gambar 1.

Peserta pelaku usaha UMKM emping dan Pemuda

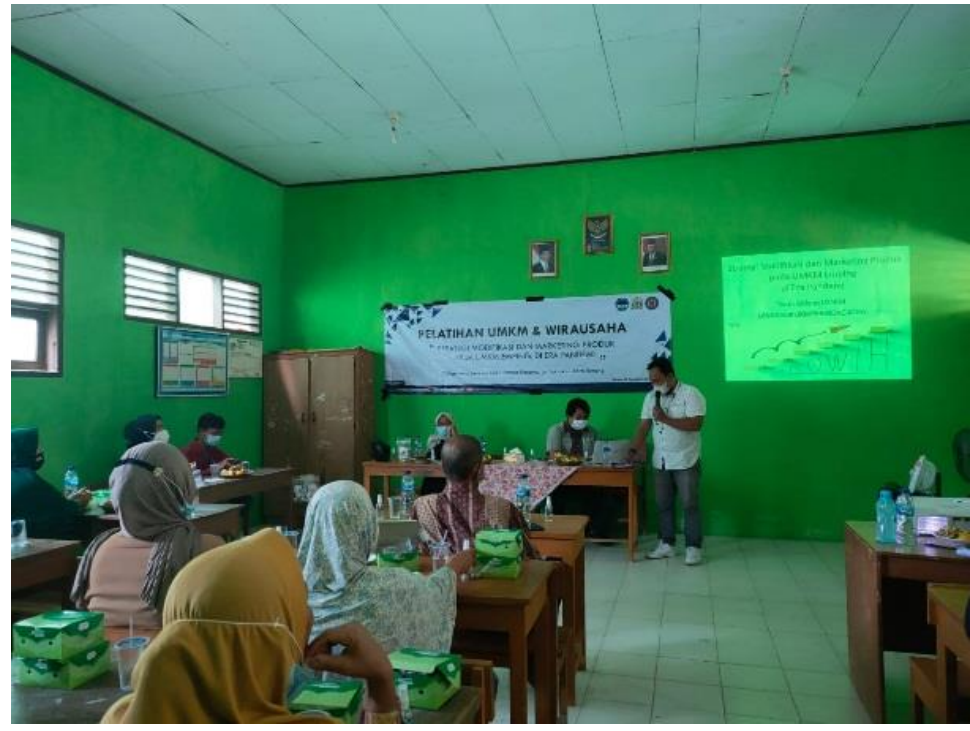

Gambar 2.

materi dan simulasi dari Tim Disperindag Kota Serang 


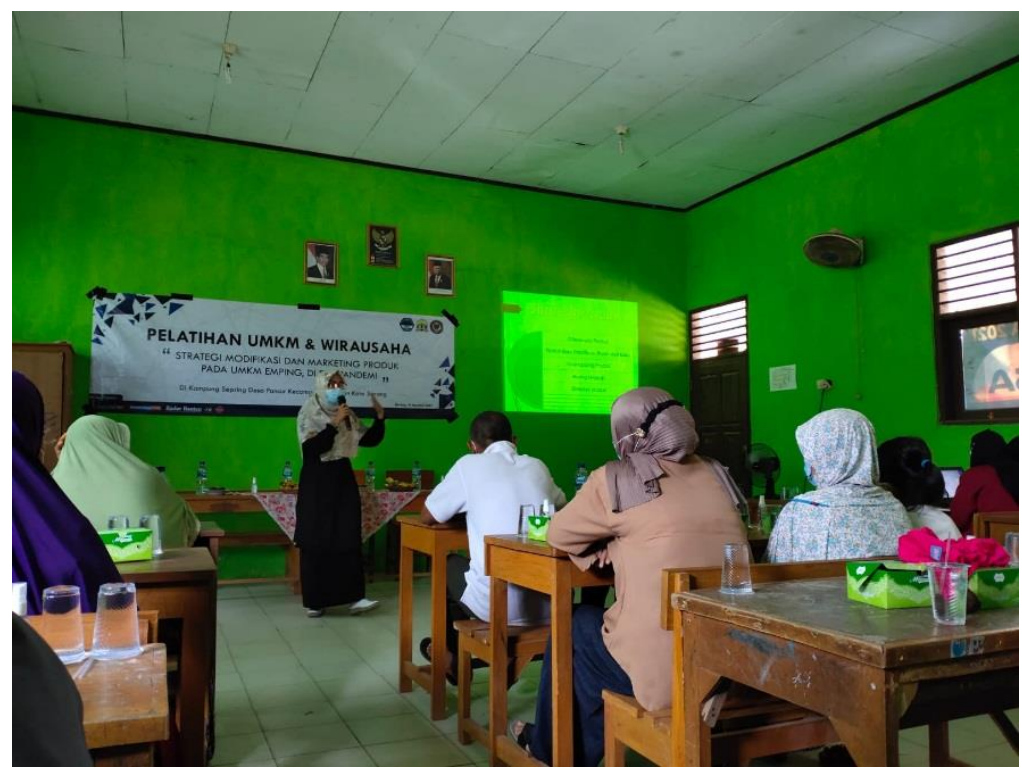

Gambar 3.

Penyampain materi sekaligus memperagakan langkah-langkah penggunaan marketing digital

\section{KESIMPULAN}

Berdasarkan pembahasan mengenai modifikasi produk dan marketing digital di era pandemic di kampung sepring desa pancur, maka disimpulkan sebagai berikut:

1. Peserta pelatihan mampu memahami pentingnya peran UMKM dalam perekonomian.

2. Peserta dapat memahami langkah-langkah yang harus dilakukan saat mengajukan perijinan legalitas baik untuk lembaga UMKM ataupun produknya.

3. Peserta mampu bekerjasama dengan Disperindag Kota Serang dalam pendampingan.

4. Mofikasi produk diperlukan dan harus dilakukan oleh UMKM emping agar tetap bisa bertahan dengan persaingan pasar, tentu saja tetap memiliki ciri khasnya sendiri. Produk olahan emping selain digoreng, salah satu modifikasi yang ditawarkan dalam pelatihan ini adalah emping coklat dan permen emping.

5. Peserta mampu menerapkan penggunaan marketplace dan onlinsehop.

6. Peserta pelatihan bisa bekerjasama baik dari pelaku usaha UMKM dan pemuda setempat, untuk peningkatan penjualan dan wirausaha. 
Berdasarkan simpulan di atas, saran yang dapat diberikan sebagai berikut:

1. Tetap menjalin kerjasama antar pihak, seperti pelaku usaha UMKM, Disperindag Kota Serang dan Pemuda khususnya desa pancur.

2. Mengurus P-IRT, label halal daan BPOM bagi produk yang belum memilikinya.

3. Pelaku usaha harus tetap melihat kondisi pasar, sehingga bisa terus berinovasi dalam produknya.

4. Pelaku usaha UMKM dan pemuda diharapkan.mengelola marketplace ataupun onlineshop untuk memasarkan produknya ke jaringan yang lebih luas.

\section{DAPTAR PUSTAKA}

\section{Sumber Buku dan Jurnal}

Fandy Tjiptono, 2008. Strategi Pemasaran. CV. Andi Offset-Yogyakarta.

Chaffey, Dave, dan PR Smith. 2013. E-marketing Excellences. UK: ButterworrthHeinemann. Heidrick and Struggles. 2009. The Adoption of Digital Marketing in Financial. Services Under Crisis.

Kotler dan Keller. 2009. Manajemen Pemasaran, Edisi 13. Jakarta: Erlangga.

Kotler, Philip. 2009. Manajemen Pemasaran, Edisi 13. Jakarta: Erlangga.

Kotler \& Keller. 2012. Marketing Management. New Jersey: Pearson Prentice

Eka Rahma, Dkk. 2021. Pelatihan pemasaran digital produk desa nadung: kopi teh pelawan dan gula.

Emilia dan Ana, 2020. Pelatihan e-commerce untuk usaha mikro kecil menengah di kota sintang.

Ginanjar, Dkk. 2020. Pelatihan digital marketing sebagai penunjang kegiatan promosi dan pemasaran.

Santi, Dkk. 2019. Inovasi Dan Peningkatan Nilai Jual Produk Hasil Umkm Melalui Pelatihan Pembuatan Bolu Kukus Berkarakter.

Sugito, Dkk. 2018. Pengabdian masyarakat pengembangan produk UMKM olahan ikan bandeng

Andi, Dkk. 2019. Peningkatan keterampilan pemasaran melalui pelatihan whatsapp business pada UMKM

\section{Sumber Internet}

http://eprints.polsri.ac.id/3004/3/BAB\%20II.pdf

https://www.beritasatu.com/ekonomi/788089/umkm-sebagai-penggerak-ekonomi-di-tengah pandemi-covid

https://www.coursehero.com/file/p3k229d/2-Modifikasi-produk-product-modification-

meningkatkan-volume-penjualan-dengan/

https://money.kompas.com/read/2021/02/23/093656826/apa-itu-dropship-apa-bedanya-

dengan-reseller 